FOLIA

HORTICULTURAE

Ann. 20/2, 2008, 39-46

DOI: $10.2478 /$ fhort-2013-0112

\title{
Some nutritional constituents in bulbs of selected Allium cultivars
}

\author{
Maria Leja ${ }^{1}$, Anna Kołton ${ }^{1}$, Iwona Kamińska ${ }^{1}$, Gabriela Wyżgolik ${ }^{1}$, \\ Wojciech Matuszak ${ }^{2}$ \\ ${ }^{1}$ Deparment of Plant Physiology \\ Faculty of Horticulture \\ University of Agriculture in Kraków \\ 29 Listopada 54, 31-425 Kraków, Poland \\ ${ }^{2}$ Vegetable Plant Breeding and Seed Production Company in Nochowo \\ Lipowa 22, 63-100 Śrem \\ e-mail:mleja@bratek.ogr.ar.krakow.pl
}

Key words: ascorbic acid, dry matter, onion, pyruvate, sugars

\begin{abstract}
Two years experiment was carried out to compare the nutritional composition in bulbs of ten onion cultivars grown in the field conditions. Pyruvic acid, ascorbic acid and soluble sugars were determined in the edible part of onion bulbs. In most cultivars the content of pyruvate as the pungency index was ranged between 3-7 $\mu \mathrm{mol} \mathrm{g}{ }^{-1}$ fresh weight (medium pungency), however, three of them exceeded $7 \mu \mathrm{mol} \mathrm{g}{ }^{-1}$ fresh weight (high pungency).

A higher level of pyruvate corresponded in most cases with higher sugar content but was not correlated with that of ascorbic acid.
\end{abstract}




\section{INTRODUCTION}

Pungency of onion which is undesirable by consumers results from the presence in bulb tissue of the volatile sulphur compounds. In desintegrated tissue S-alk(en)yl cysteine sulfoxides such as S-methyl-L-cysteine sulfoxide, S-propyl-L-cysteine sulfoxide and alliin are hydrolysed by allinase leading to formation of S-alk(en)sulfenic acid, pyruvic acid and ammonia (Schwimmer and Weston 1961, Randle and Bussard 1993). According to the last findings of Corzo-Martinez et al. (2007) the main source of lachrymatory factor (1-propanethial-S-oxide) found in onion is isoalliin (S-propen-1-yl-L-cysteine sulfoxide). The lachrymatory factor synthase was recently described by Masamura (2007). The enzymatically produced pyruvic acid is usually measured and treated as the pungency index (Schwimmer and Weston 1961, Randle 1992, Anthon and Barret 2003).

The balance between pungency and sweetness results from the volatile sulfur compounds and sugar level. The main non-structural sugars of onion bulb tissue are glucose, sucrose, fructose and fructo-oligosaccharides (O'Donoghue et al. 2004, Bufler 2007, Vagen 2007). The final taste of fresh onion depends on the mutual relation between carbohydrates and pyruvic acid.

The aim of the present investigations was to determine levels of pyruvate and soluble sugars in ten onion cultivars of long-day genotype. Additionally, ascorbic acid content was detected as the important nutritional factor.

\section{MATERIAL AND METHODS}

The experiment was carried out in 2006 and 2007. Ten onion cultivars were grown in Kraków, Poland in field conditions. All cultivars, used in the experiment were qualified as the long-day onion genotypes of different growing periods: cultivars such as 'Tęcza', 'Takstar $F_{1}$ ' and 'Majka' are very early; 'Zeta' and 'Scarlet' mid-early; 'Alibaba', 'Dakota $\mathrm{F}_{1}$ ' and 'Vectra $\mathrm{F}_{1}$ ' - mid-late cultivars; 'Bila' and 'Sumatra $F_{1}$ ' belong to the late group.

According to the soil analysis, mineral compounds were supplemented to the 190, 70 and $60 \mathrm{mg} \mathrm{dm}^{-3}$ for $\mathrm{K}, \mathrm{P}$ and $\mathrm{Mg}$, respectively. Nitrogen feeding was applied twice at the rate $60 \mathrm{~kg} \mathrm{~N}^{-1}$ before and $40 \mathrm{~kg} \mathrm{~N} \mathrm{ha}^{-1}$ after planting.

Plants were produced in greenhouse from seed obtained by the "Spójnia" Hodowla i Nasiennictwo Ogrodnicze (Vegetable Plant Breeding and Seed Production Company) and planted on $27^{\text {th }}$ April and on $19^{\text {th }}$ April in 2006 and 2007, respectively. During growth the common cultivation and protection procedure recommended for onion was applied. 
After harvesting (the middle of August and the end of July in 2006 and 2007, respectively) onion bulbs were kept for 2-3 weeks at low humidity and then taken for chemical analysis. Thirty bulbs were used as the laboratory mean sample.

Pyruvic acid content was determined according to the classical method of Schwimmer and Weston (1961) with 2,4-dinitrophenylhydrazine reagent, modified by Ketter and Randle (1998). For thermic allinase inactivation to measure the background level of pyruvate microwave oven was used.

Total soluble sugars were measured by the colorimetric method with antrone reagent (Yemm and Wills 1954). Ascorbic acid level was estimated by the iodine titration method given by Duliński et al. (1988). Dry matter content was determined by drying the samples of fresh material at $105^{\circ} \mathrm{C}$.

All the analyses were made in three replications and the results were statistically evaluated by the Fisher's test for $\mathrm{p}=0.05$.

\section{RESULTS AND DISCUSSION}

According to results presented in Table 1 the pyruvate level estimated in ten various onion cultivars ranged between 3.35 to $8.13 \mu \mathrm{mol} \mathrm{g}^{-1}$ of fresh weight for 'Tęcza' in 2007 and 'Scarlet' in 2006, respectively. Similar contents of pyruvate (4.30-12.34 $\mu \mathrm{mol} \mathrm{g}^{-1}$ f.w.) were reported by Anthon and Barret (2003), by Kopsell and Randle in 1997 (6.3-12.8) and by Gallina et al. in 2007 (4.5-12.5). Low, mid and high pungency of onion has been definied as 0-3, 3-7 and above $7 \mu \mathrm{mol}$ of pyruvic acid per gram of fresh weight (Mkseeds 2005). None of cultivars investigated in the present study belongs to the sweet (low pungency) onions, most of them can be qualified as medium ones, in two cultivars ('Alibaba' and 'Scarlet') the pyruvic acid level exceeded $7 \mu \mathrm{mol} \mathrm{g}^{-1}$ fresh weight (high pungency) (mean for two years of investigations).

Some authors found correlation between onion genotype (short day, intermediate day, long day) and their pungency (Kopsell and Randle 1997, Sorenson 2007). According to their reports the short-day and intermediate-day onions are considered as less pungent (sweet) ones. This dependence was not observed in the present study. All cultivars, used in our experiment were qualified as the long-day onion genotypes of different growing periods. In very-early cultivars concentration of pyruvic acid was lowest, however, the highest level of this compound was observed in mid-early ('Scarlet') and in mid-late ('Alibaba') ones. Gallina et al. (2007) reported that the more precocious group showed lower pyruvate content than medium and delayed maturation group, however, the precocity affected the pungency less distinctly than tunic color.

The effect of tunic color on pungency was reported by Gallina et al. (2007). The authors investigated ninety seven onion genotypes ( 26 white, 41 yellow and 30 
red) and found significantly lower concentration of pyruvate in the white group onion in comparison with the red and yellow ones. In our experiment both in onion bulbs of 'Alibaba' (white tunic) and 'Scarlet' (red tunic) high level of pyruvate was found, exceeding slightly that of the other (yellow) cultivars.

Table 1. Pyruvic acid and dry matter content in bulbs of selected Allium cultivars

\begin{tabular}{|c|c|c|c|c|c|c|c|}
\hline \multirow{2}{*}{ Object } & \multicolumn{3}{|c|}{$\begin{array}{c}\text { Pyruvic acid } \\
{\left[\mu \mathrm{mol} \mathrm{g}^{-1}\right]}\end{array}$} & \multirow{2}{*}{ Object } & \multicolumn{3}{|c|}{$\begin{array}{c}\text { Dry matter } \\
{[\%]}\end{array}$} \\
\hline & 2006 & 2007 & Average & & 2006 & 2007 & Average \\
\hline 'Alibaba' & $7.3 \mathrm{~h}^{*}$ & $6.8 \mathrm{~g}$ & 7.1 & 'Alibaba' & $12.5 \mathrm{j}$ & $11.8 \mathrm{hi}$ & 12.1 \\
\hline 'Bila' & $6.0 \mathrm{f}$ & $5.4 \mathrm{de}$ & 5.7 & 'Bila' & $10.3 \mathrm{de}$ & $9.4 \mathrm{c}$ & 9.8 \\
\hline 'Dakota $F_{1}$ ' & $5.9 \mathrm{f}$ & $5.9 \mathrm{f}$ & 5.9 & 'Dakota $F_{1}$ ' & $11.4 \mathrm{gh}$ & $10.1 \mathrm{~d}$ & 10.8 \\
\hline 'Majka' & $5.7 \mathrm{ef}$ & $5.1 \mathrm{~d}$ & 5.4 & 'Majka' & $7.8 \mathrm{a}$ & $8.2 \mathrm{ab}$ & 8.0 \\
\hline 'Scarlet' & $8.1 \mathrm{i}$ & $7.1 \mathrm{gh}$ & 7.6 & 'Scarlet' & $12.1 \mathrm{ij}$ & $11.6 \mathrm{gh}$ & 11.0 \\
\hline 'Sumatra $F_{1}$ ' & $7.2 \mathrm{~h}$ & $6.8 \mathrm{~g}$ & 7.0 & 'Sumatra $F_{1}$ ' & $11.1 \mathrm{fg}$ & $10.6 \mathrm{de}$ & 10.8 \\
\hline 'Takstar $\mathrm{F}_{1}$ ' & $4.6 \mathrm{c}$ & $4.2 \mathrm{~b}$ & 4.4 & 'Takstar $\mathrm{F}_{1}$ ' & $8.0 \mathrm{ab}$ & $8.3 \mathrm{~b}$ & 8.1 \\
\hline 'Tęcza' & $4.5 \mathrm{bc}$ & $3.4 \mathrm{a}$ & 3.9 & 'Tęcza' & $9.5 \mathrm{c}$ & $8.4 \mathrm{~b}$ & 8.9 \\
\hline 'Vectra $F_{1}$ ' & $5.2 \mathrm{~d}$ & $5.9 \mathrm{f}$ & 5.6 & 'Vectra $F_{1}$ ' & $10.7 \mathrm{ef}$ & $11.7 \mathrm{hi}$ & 11.2 \\
\hline 'Zeta' & $6.0 \mathrm{f}$ & $5.8 \mathrm{f}$ & 5.9 & 'Zeta' & $8.3 \mathrm{~b}$ & $8.2 \mathrm{ab}$ & 8.2 \\
\hline
\end{tabular}

* values designated with the same letters within columns do not significantly differ at $p=0.05$.

Table 2. Level of ascorbic acid and soluble sugars in fresh weight of bulbs of selected Allium cultivars

\begin{tabular}{|c|c|c|c|c|c|c|c|}
\hline \multirow[t]{2}{*}{ Object } & \multicolumn{3}{|c|}{$\begin{array}{c}\text { Soluble sugars } \\
{[\%]}\end{array}$} & \multirow[t]{2}{*}{ Object } & \multicolumn{3}{|c|}{$\begin{array}{c}\text { Ascorbic acid } \\
{\left[\mathrm{mg} 100 \mathrm{~g}^{-1}\right]}\end{array}$} \\
\hline & 2006 & 2007 & Average & & 2006 & 2007 & Average \\
\hline 'Alibaba' & $6.9 \mathrm{~h}$ & $7.3 \mathrm{j}$ & 7.1 & 'Alibaba' & $9.0 \mathrm{fg}$ & $9.0 \mathrm{fg}$ & 9.0 \\
\hline 'Bila' & $5.7 \mathrm{c}$ & $6.4 \mathrm{e}$ & 6.1 & 'Bila' & $9.0 \mathrm{fg}$ & $9.5 \mathrm{~g}$ & 9.2 \\
\hline 'Dakota $F_{1}$ ' & $6.6 \mathrm{f}$ & $7.1 \mathrm{i}$ & 6.9 & 'Dakota $F_{1}$ ' & $7.5 \mathrm{c}$ & 8.8 efg & 8.1 \\
\hline 'Majka' & $4.7 \mathrm{a}$ & $7.7 \mathrm{k}$ & 6.2 & 'Majka' & $8.1 \mathrm{cde}$ & $6.2 \mathrm{~b}$ & 7.2 \\
\hline 'Scarlet' & 8.51 & $6.7 \mathrm{~g}$ & 7.6 & 'Scarlet' & $9.0 \mathrm{fg}$ & $7.9 \mathrm{~cd}$ & 8.5 \\
\hline 'Sumatra $F_{1}$ ' & $7.2 \mathrm{ij}$ & $7.0 \mathrm{~h}$ & 7.1 & 'Sumatra $\mathrm{F}_{1}$ ' & $4.0 \mathrm{a}$ & $7.9 \mathrm{~cd}$ & 5.9 \\
\hline 'Takstar $\mathrm{F}_{1}$ ' & $5.1 \mathrm{~b}$ & $6.5 \mathrm{e}$ & 5.8 & 'Takstar $\mathrm{F}_{1}$ ' & $10.8 \mathrm{~h}$ & $7.5 \mathrm{c}$ & 9.1 \\
\hline 'Tęcza' & $6.8 \mathrm{~g}$ & $6.2 \mathrm{~d}$ & 6.5 & 'Tęcza' & $7.7 \mathrm{~cd}$ & $6.2 \mathrm{~b}$ & 6.9 \\
\hline 'Vectra $F_{1}$ ' & $7.3 \mathrm{j}$ & $6.3 \mathrm{~d}$ & 6.8 & 'Vectra $F_{1}$ ' & $4.0 \mathrm{a}$ & $8.4 \mathrm{def}$ & 6.2 \\
\hline 'Zeta' & $7.2 \mathrm{i}$ & $6.7 \mathrm{fg}$ & 6.9 & 'Zeta' & $7.7 \mathrm{~cd}$ & $6.4 \mathrm{~b}$ & 7.0 \\
\hline
\end{tabular}

Pyruvate contents measured in 2007 were in most cases (seven cultivars) significantly lower as related to results of the previous year (Table 1), one ('Vectra') cultivar reacted with elevated level of this compound while pyruvate content remained the same in bulbs of 'Zeta' and 'Dakota'. This phenomenon might have been due to higher rainfall in July 2007 in comparison with the previous year (Fig. 1) just before the harvest time. The dry matter content measured in 2007 was also, in most cases slightly lower than in 2006 (Table 1). 
The lowest and the highest level of soluble sugars was noticed in 'Majka' $(4.72 \%)$ and in 'Scarlet' (8.51\%) cultivars in 2006 (Table 2). In the bulbs of the other cultivars variability was less distinct. The significant increase in total sugars in 2007 was observed in five cultivars, in five of them decrease was found, so the fluctuation caused by the climate conditions found in the case of pyruvate was not observed.

Sugar composition of the cultivars varied: approximately half of the mono- and disaccharides content is glucose, the relations between sucrose and fructose levels are differentiated (O'Donoghue et al. 2004). Onion sweetness is caused by glucose, sucrose and fructose, the sweetness of the latter is $170 \%$ in comparison with the sucrose expressed as $100 \%$. Short-day cultivars have higher level of sucrose, glucose and fructose and low content of non-sweet fructans, while long-day cultivars have higher amounts of fructans (Mkseeds 2005).

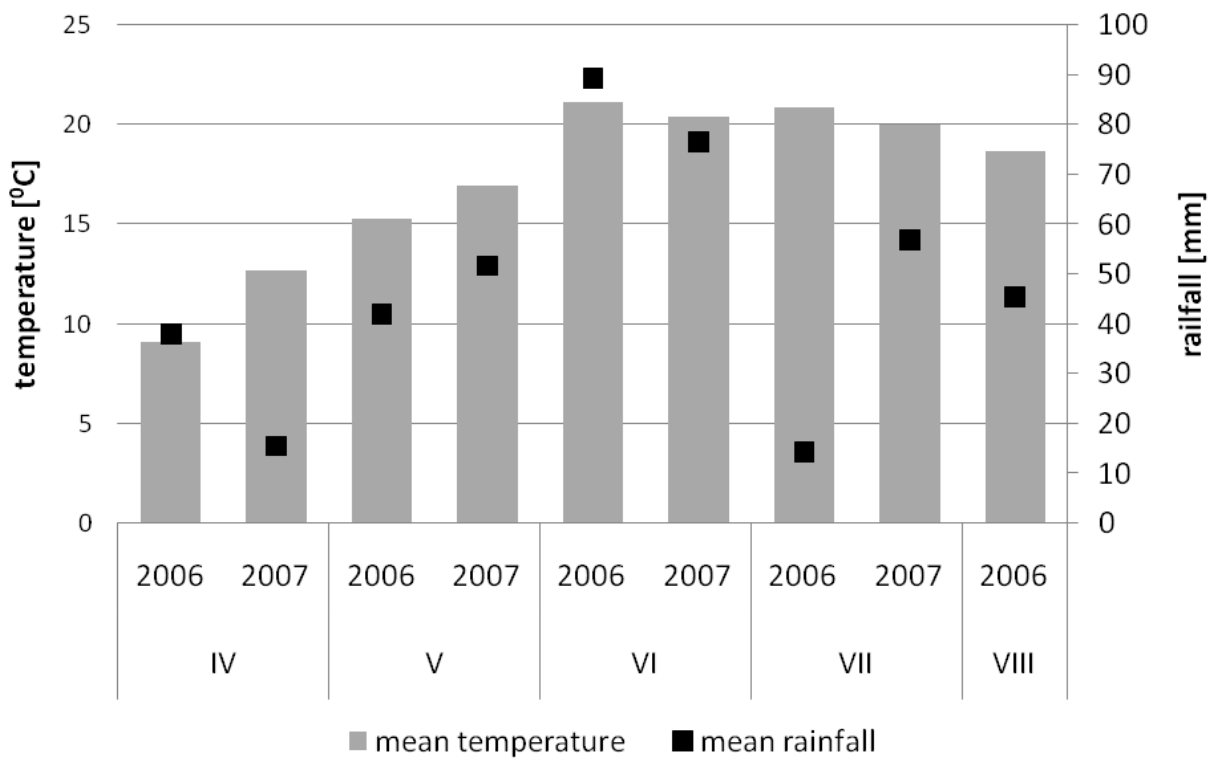

Fig. 1. Mean rainfalls and temperatures during growing seasons

In the present study total soluble sugars were determined so the participation of individual mono and disaccharides as well as that of fructans was unknown, however, the high content of non-sweet fructans might be possible in long-day onion genotypes used in the experiment. Balance between pyruvate (pungency) and soluble sugar content determines the perception of sweetness: according to the presented results the cultivars of high sugar level had the highest level of pyruvate ('Alibaba', 'Sumatra' and 'Scarlet'), so among the investigated cultivars the best 
one (low pyruvate level accompanied by the relatively high sugar content) seems to be 'Tęcza'.

Onion does not belong to vegetables of high vitamin $\mathrm{C}$ content, however, its level has a certain effect on the nutritional quality of the crop. According to the presented results ascorbic acid level was greatly differentiated both in the investigated cultivars and in the years of experiment (Table 2). The lowest contents of ascorbic acid were found in 2006 in the case of 'Sumatra' and 'Vectra' cultivars (3.96 mg $100 \mathrm{~g}^{-1}$ ) while the highest level of this compound was observed in bulbs of 'Takstar' (10.78 mg $100 \mathrm{~g}^{-1}$ in 2006) and in 'Bila' and 'Alibaba' (over $9.0 \mathrm{mg}$ $100 \mathrm{~g}^{-1}$ in both years). Ascorbic acid content in bulbs of the investigated cultivars was, in general, higher than vitamin $\mathrm{C}$ determined in the popular in Poland 'Wolska' cultivar (4.5 mg $100 \mathrm{~g}^{-1}$ ) (Franczuk 2000). In 2007 a slight decrease in ascorbic acid content was observed in five cultivars, in four of them the significant increase was noticed while only in one ('Alibaba') the same level of vitamin $\mathrm{C}$ as in 2006 was shown. Ascorbic acid level in onion bulbs seems to be greatly dependent on the growing conditions: its concentration in the bulbs of 'Wenta' cultivar from ecological cultivation reached $30 \mathrm{mg} 100 \mathrm{~g}^{-1}$ and was twice higher when compared to conventional growing method (Hallman and Rembiałkowska 2006). In the present experiment the effect of climate conditions was not observed. The same authors (Hallman and Rembiałkowska 2006) found also higher ascorbic acid content in red onions than in the yellow ones, however, in the present experiment the highest vitamin C content was determined in yellow ('Takstar' and 'Bila') and in white ('Alibaba') cultivars.

Dry matter content in onion bulbs ranged from $7.79 \%$ to $12.45 \%$ ('Majka' and 'Alibaba' cultivars, respectively). They can be divided into two groups of relatively low (below 10\%) and high (above 10\%) dry matter level. Sinclair et al. (1995) qualify onion cultivars of lower than $15 \%$ dry matter as better for fresh consumption than those of $15-20 \%$ useful for dehydration. According to their report all cultivars studied in our experiment can be treated as salad group, preferred recently in most of UE countries.

In general, ten onion cultivars of long-day genotype selected for the present experiment seem to have good nutritional quality and can be recommended for consumption.

\section{REFERENCES}

ANTHON G.E., BARRETT D.M., 2003. Modified method for the determination of pyruvic acid with dinitrophenylhydrazine in the assessment of onion pungency. J. Sci. Food Agric. 83: 1210-1213. 
BUFLER G., 2007. Ethylene inhibits sprout growth of onion bulbs during cold storage. $5^{\text {th }}$ International Symosium on Edible Alliaceae. De Meerpaal, Dronten, Holandia. ISHS: 79-80.

Corzo-Martinez M., CORzo N., Villamiel M., 2007. Biological properties of onions and garlic. Trends Food Sci. Technol. 18: 609-625.

DULIŃSKI J., LEJA M., SAMOTUS B., ŚCIGALSKI A., 1988. Wybrane metody analizy materiałów roślinnych. AR Kraków, Skrypty dla Szkół Wyższych: 53-56.

FrANCZUK J., 2000. Zmiany zawartości witaminy C w cebuli odmiany Wolska w zależności od rodzaju nawożenia organicznego. Zesz. Nauk. AR Kraków 364: 87-90.

Gallina M.P., Cabassi G., Maggioni A., Marini A., Ferrante A., 2007. Correlation and distribution analyses between pyruvic acid content and phenotypic traits of onion bulbs. $5^{\text {th }}$ International Symosium on Edible Alliaceae. De Meerpaal, Dronten, Holandia. (unpublished)

HaLlmanN E., RembiaŁKOWSKA E., 2006. Antioxidant compounds content in selected onion bulbs from organic and conventional cultivation. J. Res. Appl. Agric. Eng. 51(2): 42-46.

Ketter C.A.T., RAndLE W.M., 1998. Pungency assessment in onions. Tested Studies for Laboratory Teaching 19: 177-196.

KOPSELl D.E., RANDLE W.M., 1997. Onion cultivars differ in pungency and bulb quality changes during storage. HortSci. 32(7): 1260-1263.

MASAMURA N., 2007. Searching for amino acid residues essential for enzymatic activity in onion lachrymatory factor synthase (LFS). $5^{\text {th }}$ International Symosium on Edible Alliaceae. De Meerpaal, Dronten, Holandia. ISHS: 139-141.

O’Donoghue E.M., Somerfield S.D., Shaw M., Bendall M., Hedderly D., EASON J., SIMS I., 2004. Evaluation of carbohydrates in Pukekohe Longkeeper and Grano cultivars of Allium cepa. J. Agric. Food Chem. 52: 5383-5390.

RANDLE W.M., 1992. Sampling procedures to estimate flavor potential in onion. HortSci. 27(10): 1116-1117.

RANDLE W.M., BUSSARD M.L., 1993. Streamlining onion pungency analyses. HortSci. 28(1): 60.

SCHWIMMER S., WESTON W.J., 1961. Enzymatic development of pyruvic acid in onion as a measure of pungency. J. Agr. Food Chem. 9(4): 301-304.

SINCLAIR P.J., BLAKENEY A.B., BARLOW E.W.R., 1995. Relationships between bulb dry matter content, solube solids concentation and non-structural carbohydrate composition in the onion (Allium cepa). J. Sci. Food Agric. 69: 203-209. 
SORENSON J.N., 2007. Yield and pungency of sweet onions grown at long-day conditions. $5^{\text {th }}$ International Symosium on Edible Alliaceae. De Meerpaal, Dronten, Holandia. ISHS: 57-59.

VAGEN I.M., 2007. Effects of field curing and defoliation on contents of carbohydrates and flavonoids in onion (Allium cepa). $5^{\text {th }}$ International Symosium on Edible Alliaceae. De Meerpaal, Dronten, Holandia. ISHS: 124-126.

YEMM E.W., WILLS A.J., 1954. The estimation of carbohydrates in plant extracts by antrone. Biochem. J. 57: 508-514.

Mkseeds, 2005. www.mkseeds.com.au/sweet.htm

\section{NIEKTÓRE SKŁADNIKI POKARMOWE W CEBULACH WYBRANYCH ODMIAN ALLIUM}

Streszczenie: Przeprowadzono dwuletnie doświadczenie w celu porównania zawartości wybranych składników żywieniowych w cebulach dziesięciu odmian cebuli jadalnej uprawianej $\mathrm{w}$ warunkach polowych. W jadalnych częściach oznaczono kwas pirogronowy, cukry rozpuszczalne i kwas askorbinowy. W większości badanych odmian zawartość pirogronianu stanowiąca wskaźnik ostrości smaku była zawarta $\mathrm{w}$ przedziale 3-7 $\mu \mathrm{mol} \mathrm{g}^{-1}$ świeżej masy (średnia ostrość), jakkolwiek trzy z nich charakteryzowały się poziomem tego składnika przekraczającym $7 \mu \mathrm{mol} \mathrm{g}{ }^{-1}$ świeżej masy (wysoka ostrość).

W większości przypadków wyższy poziom pirogronianu korespondował z większą zawartością cukrów, nie był natomiast skorelowany z zawartością kwasu askorbinowego. 